\title{
COMPOSITION OF SOME APRICOT (PRUNUS ARMENIACA L.) KERNELS GROWN IN TURKEY
}

\author{
M. ÖZCAN \\ Department of Food Engineering, Faculty of Agriculture, Selçuk University, 42031, Konya. Turkey \\ (Received: 4 January 1999; accepted: 2 March 2000) \\ The 4 apricot kernel samples provided from Malatya province were evaluated for \\ moisture, ash, crude protein, crude oil, crude fibre, crude energy, non-soluble $\mathrm{HCl}$ acid ash, mass \\ of 100 pits and mass of 100 kernels. Contents of $\mathrm{Na}, \mathrm{P}, \mathrm{K}, \mathrm{Ca}, \mathrm{Mg}, \mathrm{Fe}, \mathrm{Zn}, \mathrm{Mn}$ and $\mathrm{Cu}$ were also \\ determined in the samples.
}

Keywords: apricot, kernels, physical and chemical properties

Apricot (Prunus armeniaca L.; Rosaceae) is the most important fruit crop in Turkey. Kernels of some apricots are sweet, and can be eaten as roasted and salted titbit. The dried product made from apricot kernels is known as "mışmış". The most important apricot varieties grown and used as dried fruit are Çataloğlu, Çöloğlu, Hacihaliloğlu and Hasanbey. In addition to these, Ordubat, Şam, Şalak, Şekerpare, Tokaloğlu and Teberze cultivars are table fruits.

ABD EL-AAL and co-workers (1986 a,b) reported that there is an important proportion of oil (50\%) and other compounds such as benzaldehyde, surface active agents and proteins in Egyptian apricot kernels. In an other study, it was established that there is an average 44\% oil in kernels (JOSHI et al., 1986). BEYER and MELTON (1990) have studied the composition of New Zealand apricot kernels. TUNCEL (1990) investigated toxicological, nutritional and microbiological characteristics of tempe fermentation with Rhizopus oligosporus of bitter and sweet apricot seeds. CANELLAS and co-workers (1992) investigated the chemical composition of the seed shell of apricot (Prunus armeniaca L.). Acid and neutral detergent fibres and their fractions hemicellulose, cellulose and lignin - were determined. Concentration of oils, soluble sugars, pectins, polyphenolic compounds, proteins and mineral elements were also determined. 
The purpose of this study was to determine the physical-chemical properties and mineral contents of kernels obtained from Çataloğlu, Çöloğlu, Hacihaliloğlu and Hasanbey varieties. It may assist in the assessment of human nutrition.

\section{Materials and methods}

\subsection{Materials}

Apricot pits were obtained from Malatya province in Turkey. They were collected during July and August in 1997. Çataloğlu, Hacihaliloğlu and Hasanbey kernels are sweet but Çöloğlu variety is bitter. Pits were transported in polypropylene bags and held at room temperature. The endocarp was removed from kernels by hand. Kernels were dried to constant weight in room temperature for analyses. Samples $(200 \mathrm{~g})$ were blended in a grinder before analyses.

\subsection{Methods}

Mass of 100 pits and the weight of 100 kernels were determined at randomized 100 pits and kernels. The chemical properties (moisture, crude oil, crude protein, crude fibre, crude ash, nonsoluble $\mathrm{HCl}$ acid ash and crude energy) and minerals ( $\mathrm{Na}, \mathrm{P}, \mathrm{K}, \mathrm{Ca}$, $\mathrm{Mg}, \mathrm{Fe}, \mathrm{Zn}, \mathrm{Mn}$, and $\mathrm{Cu}$ ) of kernels were analysed according to A.O.A.C. (1984). Results were analysed for statistical significance by analysis of variance (MINITAB, 1991), and differences among groups were established by Duncan Method (MSTAT C 1980).

\section{Results and discussion}

Physical and chemical properties and mineral contents of apricot varieties used in experiment are given in Table 1.

Moisture (4.91-5.12\%), crude oil (46.3-51.4\%), crude protein (23.58-27.70\%), crude fibre (13.49-17.98\%), crude ash (2.10-2.67\%), non soluble $\mathrm{HCl}$ ash $(0.22-0.25 \%)$, crude energy (630.0-672.4 cal $/ 100 \mathrm{~g})$, mass of 100 pits $(82-195 \mathrm{~g})$ and mass of 100 kernels (28.72-49.6 g) values were established. Crude oil, crude energy, crude fibre, crude ash, non-soluble $\mathrm{HCl}$ acid ash values and mass of 100 pits and mass of 100 kernels were the highest in Hasanbey variety. In addition to this, the highest moisture and crude protein values were measured in Çöloğlu variety $(\mathrm{P}<0.01)$.

Protein concentrations of Çataloğlu and Çöloğlu are similar to Amar (24.1\%) reported by ABD EL-AAL and co-workwers $(1986 \mathrm{a}, \mathrm{b})$. The protein content of our samples is comparable to those of Moorpark cultivar (BEYER \& MELTON, 1990), one Egyptian cultivar (bitter, SALEM \& SALEM, 1973), Morpankhar and Chavaru cultivars (JOSHI et al., 1986) (Table 1). 


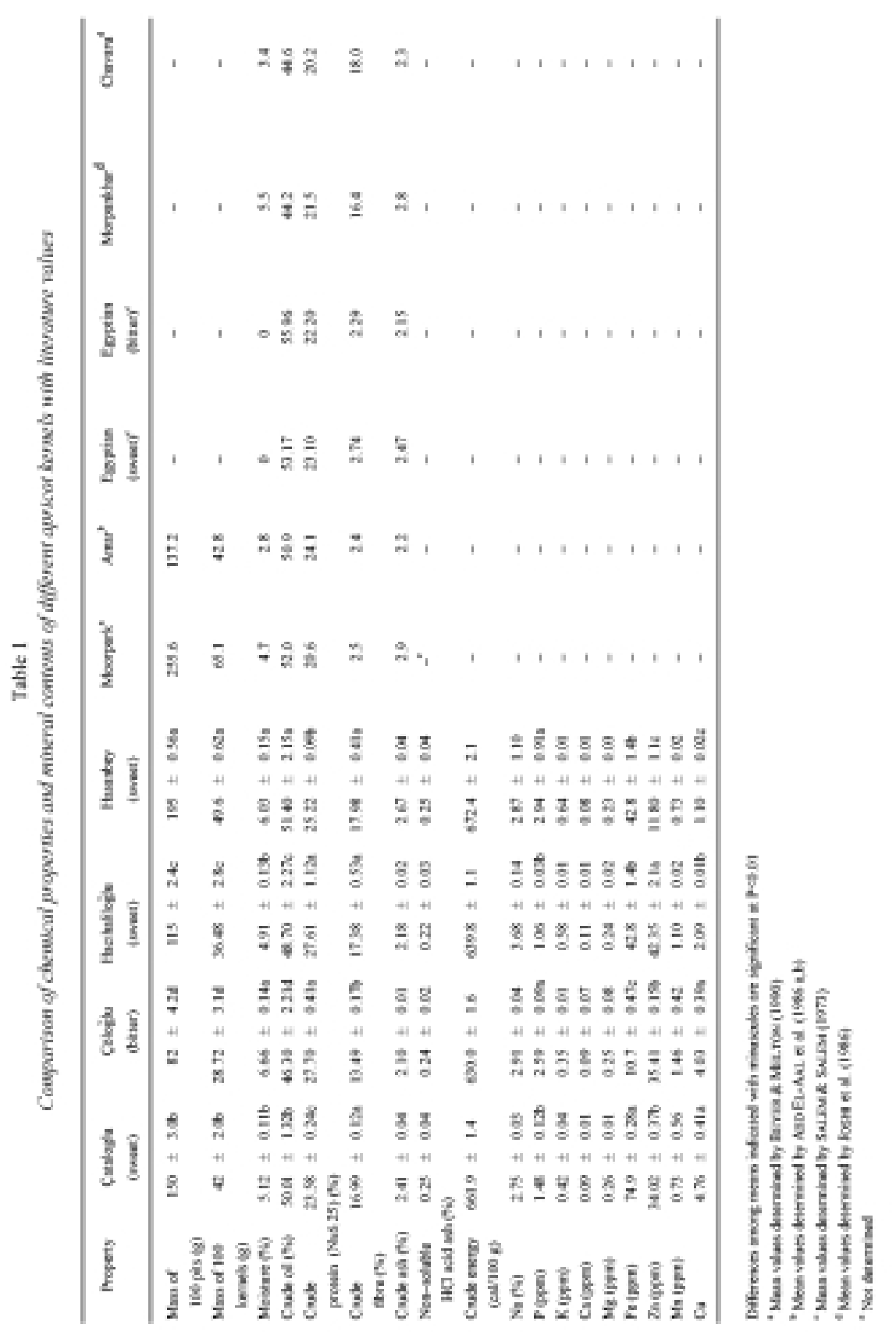

Acta Alimentaria 29, 2000 
The crude fibre contents of samples had changed between 13.49 to $17.98 \%$ $(\mathrm{P}<0.01)$. Fibre contents of Moorpark, Amar, two Egyptian kernel seeds (sweet and bitter) were found to be much less than those of the crude fibre values of our samples.

The lipid contents of the kernels were between 46.3 to $51.4 \%$, similar to that found by other workers (Table 1). The ash contents of our samples were similar to those found for the three Egyptian kernels, Moorpark and the kernels of two Indian cultivars (Table 1).

Both masses of 100 pits and 100 kernels of samples were lower than that of Moorpark cultivar, but mass values of Hasanbey variety were higher than those of the Amar variety. Also, both mass values of 100 pits and kernels were found to be statistically significant $(\mathrm{P}<0.01)$.

Mean mineral contents of varieties were found to be between $2.75-3.68 \%$ for $\mathrm{Na}$, $1.06-2.94 \mathrm{ppm}$ for $\mathrm{P}, 0.35-0.64 \mathrm{ppm}$ for $\mathrm{K}, 0.08-0.11 \mathrm{ppm}$ for $\mathrm{Ca}, 0.23-0.26 \mathrm{ppm}$ for $\mathrm{Mg}, 10.7-74.9 \mathrm{ppm}$ for $\mathrm{Fe}, 11.80-42.35 \mathrm{ppm}$ for $\mathrm{Zn}, 0.73-1.46 \mathrm{ppm}$ for $\mathrm{Mn}$ and $1.10-4.76 \mathrm{ppm}$ for $\mathrm{Cu}$ (Table 1). While $\mathrm{Fe}$ and $\mathrm{Zn}$ contents of all varieties were high, $\mathrm{Ca}, \mathrm{Mg}, \mathrm{Mn}$ and $\mathrm{K}$ were found in low amounts.

Moisture, crude oil, crude protein, crude fibre, crude ash, non-soluble $\mathrm{HCl}$ acid ash, crude energy values and mineral contents in apricot kernels are affected mainly by variety (KACAR, 1977).

Future work will also consider other compounds and composition of fatty acids of these and another apricot kernels which may be used as food.

\section{Conclusions}

The analyses results of kernels and seeds were comparable with apricot kernels such as Moorpark and Amar produced in other countries. Hasanbey variety are composed of $51.4 \%$ oil which is readily extractable. Crude oil, crude fibre, crude ash, mass of 100 pits, mass of 100 kernels and crude energy, Fe and K contents of Çöloǧlu kernel known as bitter were lower than those of other sweet varieties. So, sweet kernels can be used as baked products and roasted titbits. Future work will deal with the fatty acid composition of oils.

\section{References}

ABD EL-AAL, M. H., HAMZA, M. A. \& RAHMA, E. M. (1986a): In vitro digestibility, physicochemical and functional properties of apricot kernel proteins. Fd. Chem., 19, 197-211.

ABD El AAL, M. H., KHALIL, M. K. M. \& RAHMA, E. M. (1986b): Apricot kernel oil: characterization, chemical composition and utilisation in some baked products. Fd Chem., 19, 287-298. 
A.O.A.C. (1984): Official Methods of Analysis, Association of Official Chemistry, 14th ed. Association of Official Analytical Chemists, Arlington, VA.

BEYER, R. \& MELTON, L. D. (1990): Composition of New Zealand apricot kernels. New Zealand J. Crop Hort. Sci., 18, 39-42.

CANellas, J., FEMENIA, A., RosSELlO, C. \& SOLER, L. (1992): Chemical composition of the shell of apricot seeds. J. Sci. Fd Agric., 59, 269-271.

JOSHI, S., SRIVASTA, R. K. \& DHAR, D. N. (1986): The chemistry of Prunus armeniaca. British Fd. J., 88, 74-78, 80 .

KACAR, B. (1977): Bitki Besleme. (Plant feeding). Ankara Univ. Agric. Fac. Publ. No. 367, Ankara.

MINITAB (1991): Minitab Reference Manual (Release 7.1). Minitab Inc. State Coll., PA 16801, USA.

MSTAT C. (1980): Mstat User's Guide: Statistics (Version 5 ed.) Michigan State University, Michigan, USA.

SALEM, S. A. \& SALEM, F. M. A. (1973): Egyptian apricot kernels seeds. Dt. LebensmittRdsch., 69, 322-324.

TUNCEL, G., NOUT, M. J. R., BRIMER, L. \& GÖKTAN, D. (1990): Toxilogical, nutritional and microbiological evaluation of tempe fermentation with Rhizopus oligosporus of bitter and sweet apricot seeds. Int. J. Fd. Microbiol., 11, 337-344. 